Pascale Hubert · Roland Greimers ·

Elizabeth Franzen-Detrooz · Jean Doyen ·

Pierre Delanaye ' Jacques Boniver ·

Philippe Delvenne

\title{
In vitro propagated dendritic cells from patients with human-papilloma virus-associated preneoplastic lesions of the uterine cervix: use of Fit3 ligand
}

Received: 8 January 1998 / Accepted: 30 April 1998

\begin{abstract}
Dendritic cells (DC) are the most efficient antigen presenting cells. The clinical use of DC as vectors for antitumor and anti-infectious disease immunotherapy has been limited by their low level and accessibility in normal tissue. Substantial numbers of DC can be generated from peripheral blood cultured in the presence of interleukin-4 (IL-4) and granulocyte/ macrophage-colony-stimulating factor (GM-CSF). We showed in this study that substantial numbers of DC can be obtained from the peripheral blood of patients with (pre)neoplastic lesions of the uterine cervix. The procedure required relatively small blood samples $(10 \mathrm{ml})$ and the presence of $100 \mathrm{U} / \mathrm{ml} \mathrm{IL}-4$ and $800 \mathrm{U} / \mathrm{ml} \mathrm{GM-CSF}$ in the culture medium. There was no significant difference in the morphology, yield, phenotype and function of generated DC between patients with cervical (pre)neoplastic lesions and healthy individuals. When the hematopoietic factor Flt3 ligand (Flt3 $\mathrm{L}, 40 \mathrm{ng} / \mathrm{ml}$ ) was added, there was an average increase in the DC population of $26 \%$ compared to cultures with GM-CSF and IL-4 alone. Approximately $1.2 \times 10^{6}$ cells with the characteristics of dendritic cells could be obtained when Flt3L was included in the medium. The addition of Flt3L did not modify the phenotypic profile of DC $\left(\mathrm{HLA}-\mathrm{DR}{ }^{+}, \mathrm{CD}_{1 \mathrm{a}}{ }^{+}, \mathrm{CD} 4{ }^{+}, \mathrm{CD} 54^{+}, \mathrm{CD} 80^{+}, \mathrm{CD} 86^{+}\right.$, $\mathrm{CD} 40^{+}, \mathrm{CD}^{-}$and $\mathrm{CD} 14^{-}$). In addition, Flt3L generated functional DC capable of stimulating the proliferation of alloreactive $\mathrm{T}$ cells. These results suggest that Flt3L, in association with GM-CSF and IL-4, provides an advantageous tool for the large-scale generation of DC and that an immunotherapy based on the use of DC generated in vitro is possible in patients with (pre)neoplastic lesions of the uterine cervix.
\end{abstract}

P. Hubert $(\square) \cdot$ R. Greimers · E. Franzen-Detrooz

P. Delanaye $\cdot$ J. Boniver $\cdot$ P. Delvenne

Department of Pathology B35, CHU Sart Tilman,

4000 Liege, Belgium

J. Doyen

Department of Gynaecology, CHU Sart Tilman, 4000 Liege, Belgium
Key words Dendritic cells - Peripheral blood .

Flt3L $\cdot$ HPV $\cdot$ SIL

\section{Introduction}

Accumulation of immunological, molecular and clinical evidence has implicated human papillomavirus (HPV) infection as an essential factor in the development of invasive cervical cancer and its precursor lesions [22, 31]. Squamous intraepithelial lesions (SIL) refer to a group of premalignant changes in the epithelium of the uterine cervix that precede the onset of invasive cancer.

The general or local immune state might be expected to have a key role in host defense against HPV infection and the possible development of cervical carcinoma. The nature of an effective immune response to HPV infections is not well understood, although cell-mediated immunity is thought to be more important than humoral immunity [50]. Several studies have described a localized immune dysfunction accompanying cervical HPV infections and associated cervical lesions. Specifically, alterations in the number and cytokine profiles of $\mathrm{T}$ helper lymphocytes have been reported $[2,5,49]$. On the other hand, alterations in the density, distribution and morphology of Langerhans cells have been shown in both papillomavirus-infected and (pre)neoplastic cervical epithelium [30]. Several explanations have been proposed to explain the changes of Langerhans cells locally in SIL $[16,21,29]$. These lesions develop in the transformation zone of the cervix, where there is a low density of Langerhans cells, even in the absence of HPV infection [1, 2, 8]. Other authors have suggested that these changes might be due to the cytopathic effect of the virus [38]. Alterations of membrane molecules of infected keratinocytes (loss of E-cadherin) might contribute to the reduction of Langerhans cells or to their functional inability [48]. HPV infection of the keratinocytes has been shown to alter the production of immunoregulatory cytokines that are likely to have a stimulatory effect on Langerhans cells (tumor necrosis factor $\alpha$, TNF $\alpha$; 
granulocyte/macrophage-colony-stimulating factor, GMCSF) [27]. Another possibility is that the immunosuppressive cytokine interleukin-10 (IL-10), which is expressed in SIL, plays a role in the depletion or inhibition of Langerhans cells [13]. Langerhans cells belong to the family of dendritic cells (DC), which are the most important professional antigen-presenting cells (APC) in the immune system. Because host professional APC are among the most important elements in the induction of specific antitumor immune responses, quantitative or qualitative alterations of these cells could be partly responsible for the immunotolerance of HPV-associated cervical (pre)neoplastic lesions.

Although DC are present in small numbers, they act as sentinels of the immune system because they are widely distributed in the body [36]. DC are critically involved in the initiation of primary immune responses, in vivo graft rejection and development of T-celldependent antibodies [4, 46]. Unlike other APC (monocytes, macrophages), DC may be crucial because of their potential to recruit resting $\mathrm{T}$ cells to initiate an immune response [20]. They are very specialised in this function, as reflected by their constitutive expression of high levels of major histocompatibility complex class II molecules, adhesion molecules and expression of CD80 (B7.1) and CD86 (B7.2) on their surface $[6,10]$.

By virtue of their developed antigen-presenting capacity, DC are ideal targets to manipulate the immune system. The use of DC as cellular vectors for antitumor and anti-infectious disease vaccines or as inducers of transplantation tolerance is a promising immunotherapy strategy [26, 51]. However, the clinical feasibility of using DC as immunotherapy vectors has been hampered by their scattered location and very low frequency [7].

In recent years, several laboratories have devised different methods to amplify the number of DC by culturing DC precursors from different origins. DC can be generated from $\mathrm{CD} 34^{+}$hematopoietic progenitor cells isolated from bone marrow of healthy donors [34, 43] or from peripheral blood of cancer patients undergoing autologous stem-cell transplantation [3]. Cord blood has been reported to be another source of CD34 ${ }^{+}$ progenitor cells [40]. Both the proliferation and maturation of DC are enhanced by the cooperation of GM$\mathrm{CSF}$ and TNF $\alpha$ [35]. However, the applicability of these approaches has been somewhat limited by the low levels of $\mathrm{CD} 34^{+}$cells and by the relatively tedious techniques required. Recently, another source of DC progenitors (monocytic precursors) has been discovered in adult blood [37]. Indeed, the differentiation of DC involves at least two pathways. DC can be generated from an early bone marrow precursor $\left(\mathrm{CD} 34^{+}\right)$or from cells of the monocytic lineage $\left(\mathrm{CD} 14^{+}\right)$[32]. The monocytic precursors are induced to proliferate and to differentiate in the presence of GM-CSF and IL-4. IL-4 acts by suppressing macrophage development and by favoring differentiation of DC from monocytic precursors [19].

Whatever the approach used to obtain DC (from $\mathrm{CD}_{3}{ }^{+}$or monocytic precursors), their yield depends mainly on the initial number of precursor cells. This suggests that the ex vivo generation of large numbers of DC may benefit from the addition of hematopoietic growth factors. Flt3L is a recently identified hematopoietic growth factor [24]. It has been shown to stimulate the proliferation of hematopoietic stem and progenitor cells $[23,28]$ and to induce the proliferation and differentiation of monocytes [11].

The purposes of this study were to examine the effect of Flt3 $\mathrm{L}$ on the maturation of DC from peripheral blood and to determine whether the generation of DC differs between healthy donors and patients with cervical SIL. We have shown that Flt3L is very efficient in increasing the generation of DC from human peripheral blood mononuclear cells (PBMC), without altering their phenotype or allostimulatory capacities. No difference was observed between patients with SIL and healthy women. These results might help to improve our understanding of the role of DC in HPV infections and malignant diseases and help us to evaluate the potential use of DC in HPV-associated cancer immunotherapy.

\section{Materials and methods}

Culture medium

The medium used in this study was RPMI-1640 supplemented with $10 \%$ heat-inactivated fetal calf serum (FCS), 1\% non-essential amino acids, $1 \%$ sodium pyruvate, $50 \mu \mathrm{M}$ 2-mercaptoethanol, $30 \mathrm{U} / \mathrm{ml}$ penicillin, and $30 \mu \mathrm{g} / \mathrm{ml}$ streptomycin (all obtained from Gibco BRL, Life Technologies). This medium is reported to as complete medium.

Recombinant human cytokines and growth factors

GM-CSF $\left(11.1 \times 10^{6} \mathrm{U} / \mathrm{mg}\right)$ was kindly provided by Dr. A. Gossens (Schering-Plough, Brussels). IL-4 $\left(5 \times 10^{6} \mathrm{U} / \mathrm{mg}\right)$ and Flt3L $\left(1.1 \times 10^{6} \mathrm{U} / \mathrm{mg}-20 \mu \mathrm{g} / \mathrm{ml}\right)$ were purchased from Genzyme Diagnostics (Cambridge, Mass.).

\section{Study group}

Fifteen patients with histologically confirmed SIL of the cervix were selected for this study. Biopsies were diagnosed as low-grade SIL in five patients and as high-grade SIL in ten patients. The mean age of the group was 33 years. Six age-matched healthy volunteers were used as controls.

\section{Dendritic cell cultures}

Peripheral blood was collected on EDTA from the patients before laser conisation. In some experiments, leukocyte-enriched buffycoats were used as a source of mononuclear cells.

PBMC were isolated by Ficoll-Hypaque density-gradient centrifugation. After washings at low centrifugation speed to remove the maximum number of platelets, PBMC were plated in six-well dishes (Nunclon $\Delta$ Multidishes, Nunc, Denmark) at a density of $10 \times 10^{6}$ cells/well in $3 \mathrm{ml}$ complete medium without FCS. After $18 \mathrm{~h}$ at $37^{\circ} \mathrm{C}$, non-adherent cells were discarded by two gentle washes with $1.5 \mathrm{ml}$ complete medium. The adherent cells were cultured with $800 \mathrm{U} / \mathrm{ml} \mathrm{GM-CSF}$ and different concentrations of 
IL-4 (see results) in $3 \mathrm{ml}$ complete medium/well. These cultures were supplemented or not with different concentrations of Flt3L (see results). IL-4 was added every 2 days and cultures were fed every 3 or 4 days with fresh medium containing the appropriate cytokines. Cells were harvested at different times points (day 7, 14 and 21) for phenotypic, morphological and functional analysis. Harvesting was performed by adding $1.5 \mathrm{ml}$ EDTA $1 \mathrm{mM}$ in phosphate-buffered saline without calcium, for $20 \mathrm{~min}$ at room temperature.

Flow-cytometric cell surface marker analysis

Samples containing 4-5 $\times 10^{5}$ cells were incubated for $20 \mathrm{~min}$ at $4{ }^{\circ} \mathrm{C}$ in Hank's buffer (Life Technologies) with specific mAb (listed in Table 1). Cells were stained either directly with fluoresceinisothiocyanate(FITC)- or phycoerythrin(PE)-conjugated monoclonal antibodies (1/5 dilution), or indirectly with streptavidin-PE ( $2 \mu \mathrm{l} /$ staining, Boehringer Mannheim) or with irrelevant control isotype-matched $\mathrm{mAb}$ (Becton-Dickinson). After washing, cells were resuspended in Hank's buffer and analyzed. Two- or threefluorescent-color staining was performed. Propidium iodide $(1 \mu \mathrm{g} /$ $\mathrm{ml}$ ) was used to exclude dead cells. Cells were analyzed for fluorescence intensity on a FACStarPlus flow cytometer (Becton Dickinson). Forward light scattering, orthogonal light scattering and three fluorescence signals were determined for each cell and at least 20000 events were accumulated for each measurement.

Cytochemical staining

Cytospins of DC cultures were prepared by spinning (200 rpm) $(0.5-1) \times 10^{5}$ cells onto silanized slides and fixed in cold acetone for $3 \mathrm{~min}$. Giemsa staining was performed using standard procedures.

Mixed lymphocyte reaction assay

Stimulator populations consisted of cells grown in GM-CSF + IL$4(100 \mathrm{U} / \mathrm{ml})$ or GM-CSF + IL-4 + Flt3L for 7 days. After centrifugation for $10 \mathrm{~min}$ at $200 \mathrm{~g}$, the cells were adjusted to equal concentration in RPMI-1640 medium containing 5\% human pooled $\mathrm{AB}$ serum without exogenous cytokines and irradiated with 30 Gy. Varying numbers of stimulator cells (500-50 000 cells/well) were then added to round-bottomed 96-well plates (Nunclon) containing $1 \times 10^{5}$ allogeneic PBMC/well. The tests were performed in quintuplate. A proliferative response was measured after 6 days of culture by adding $1 \mu \mathrm{Ci}\left[{ }^{3} \mathrm{H}\right]$ thymidine to each well. Cells were harvested $18 \mathrm{~h}$ later by an automated sample harvester (Packard, Canberra, Tilburg, The Netherlands) and counted in a liquid scintillation counter (Top Count, Packard, Canberra). Thymidine uptake in irradiated stimulator cells was below $640 \mathrm{cpm}$ and in responder cells cultures alone it was below $240 \mathrm{cpm}$.

Table 1 List of antibodies. Sources: Becton Dickinson (Erembodegem, Belgium). (BD); Ortho Diagnostics (Raritan, N. J.) (Ortho); Dako (Glostrup, Denmark); Pharmingen (San Diego, Calif.). FITC fluorescein isothiocyanate, $P E$ phycoerythrin

\begin{tabular}{llll}
\hline Marker & mAb & Conjugated & Source \\
\hline CD1a & OKT6 & FITC & Ortho \\
CD3 & Leu-4 & PE & BD \\
CD4 & Leu-3a & PE & Dako \\
CD14 & Leu-M3 & PE & BD \\
CD54 & ICAM-1 & PE & Pharmingen \\
CD80 & BB1/B7.1 & PE & BD \\
CD86 & B70/B7.2 & Biotin & Pharmingen \\
HLA-DR & HLA-DR & PE & BD \\
\hline
\end{tabular}

Statistical analysis

In experiments concerning the effect of Flt3L on HPV patients compared with healthy donors, the Mann-Whitney test for paired samples was used for statistical evaluation. In other experiments, the analysis of variance test for paired samples was used.

\section{Results}

Assessment of the optimal culture conditions for the generation of DC from adherent PBMC

Before working on the generation of DC from the peripheral blood of patients with SIL, we optimised the IL4 concentration in the cultures by using buffy-coat samples from normal donors as sources of PBMC. Following the 18 -h adherence to plastic at $37^{\circ} \mathrm{C}$, we observed an adherent fraction made up of monocytes $(47 \pm 10 \%)$ and lymphocytes $(41.9 \pm 22 \%)$. This adherent fraction was cultured in RPMI-1640/10\% FCS supplemented with $800 \mathrm{U} / \mathrm{ml}$ GM-CSF, as recommended by previous studies [29, 33], and various concentrations of IL-4 (0-1000 U/ml). Fluorescenceactivated cell sorting (FACS) analysis, with an antiCD1a monoclonal antibody, was performed to determine the yield of DC obtained after 7, 14 and 21 days of culture. Figure 1A shows the results expressed as the percentage increase of $\mathrm{CD} \mathrm{a}^{+}$cells in the presence of various doses of IL-4 compared with cultures containing GM-CSF alone. The maximum yield of $\mathrm{CD} \mathrm{a}^{+}$cell was observed at day 7 of culture with $100 \mathrm{U} / \mathrm{ml}$ IL-4 $(P<0.001)$. With these culture conditions, $63 \pm 18 \%$ of the cells showed a phenotype of differentiated DC $\left(\mathrm{CD} 1 \mathrm{a}^{+} / \mathrm{CD} 14^{-}\right)$. The range of increase, compared with $\mathrm{CD} 1 \mathrm{a}^{+}$cells obtained at day 7 with $1000 \mathrm{U} / \mathrm{ml}$ of IL-4, was $30 \%-50 \%$. After long-term cultures (14 and 21 days), the number of total nucleated cells decreased as well as the yield of DC. This observation was documented in four independent cell cultures.

We also tested the effect of graded doses of Flt3L $(0-80 \mathrm{ng} / \mathrm{ml})$ on PBMC from buffy-coats of healthy donors. Flt3L, at a concentration of $40 \mathrm{ng} / \mathrm{ml}$, in association with GM-CSF and IL-4, induced the maximal expansion of $\mathrm{CD} \mathrm{a}^{+}$cells in all donors examined. We showed that these conditions were responsible for a mean increase of $50 \%$ in the number of DC $(P<0.001)$ (Fig. 1B).

For subsequent experiments, we therefore decided to use $40 \mathrm{ng} / \mathrm{ml} \mathrm{Flt3L}, 100 \mathrm{U} / \mathrm{ml} \mathrm{IL-4}$ and $800 \mathrm{U} / \mathrm{ml}$ GM-CSF to generate DC.

Morphological and phenotypical analysis of $\mathrm{CD} 1 \mathrm{a}^{+}$cells cultures in the presence of Flt3L

The monocytic adherent fraction of $10 \times 10^{6}$ mononuclear cells from peripheral blood of patients with SIL or from healthy individuals was cultured in medium containing GM-CSF $(800 \mathrm{U} / \mathrm{ml})$ and IL-4 $(100 \mathrm{U} / \mathrm{ml})$ sup- 

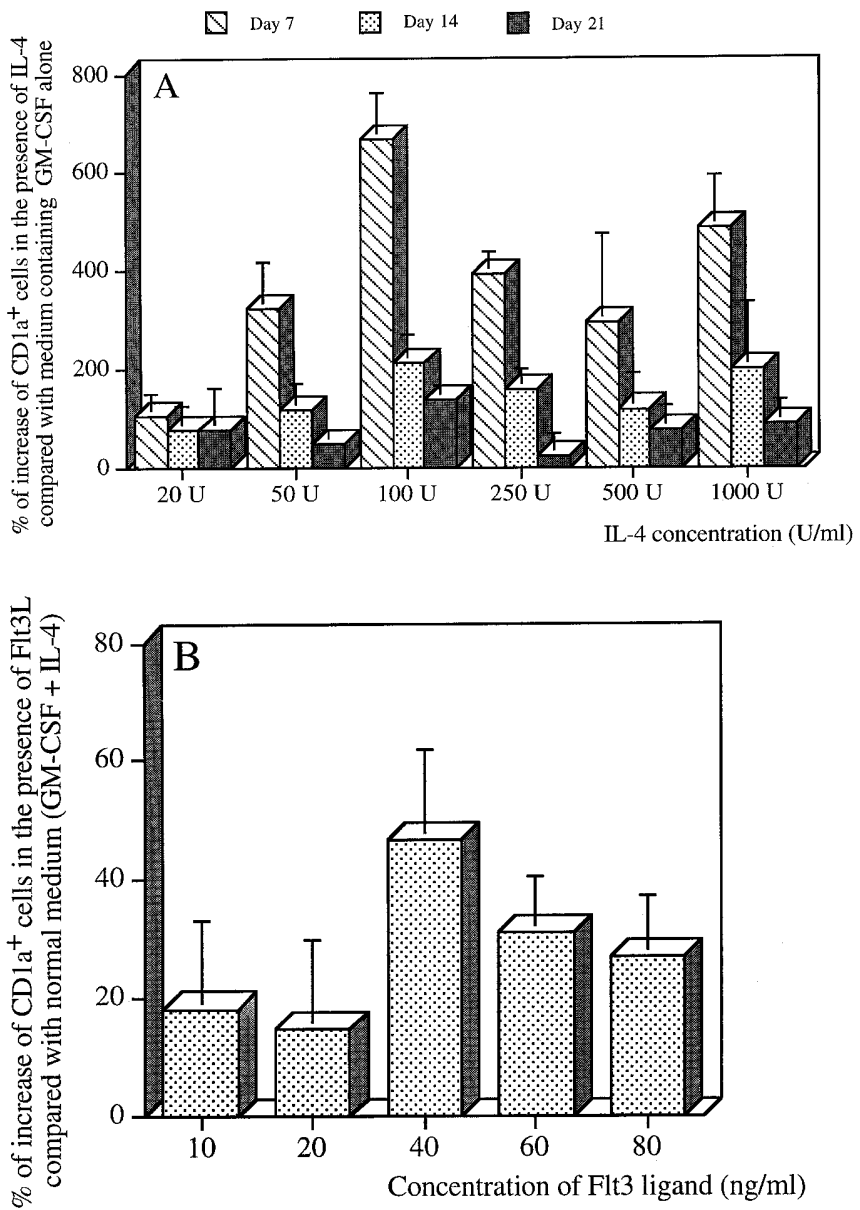

Fig. 1A, B Assessement of the optimal culture conditions for the generation of dendritic cells (DC) from adherent peripheral blood mononuclear cells (PBMC). A Average percentage $\mathrm{CDla}^{+}$cell increase in the presence of $100 \mathrm{U} / \mathrm{ml}$ interleukin-4 (IL-4). Means (bars SE) of four experiments are shown. B Effect of different concentrations of Flt3L on the number of $\mathrm{CD} \mathrm{a}^{+}$cells obtained per well. Results are presented the percentage increase compared with cultures containing normal medium [granulocyte/macrophage-colony-stimulating factor $(G M-C S F)+$ IL-4]. Means (bars $\mathrm{SE})$ of three experiments are shown

plemented or not with Flt3L at a concentration of $40 \mathrm{ng} /$ $\mathrm{ml}$, as previously determined. Phase-contrast microscopy of these cultures, with or without Flt3L, revealed the presence of cell aggregates containing a few cells after 2-3 days. These aggregates enlarged over the next few days (day 4-5) indicating proliferative activity. Many of the cells displayed the typical cytoplasmic processes (usually termed veils) peculiar to DC (data not shown). Over the next few days, these veiled DC were slowly released. There was no morphological difference between cells cultured with GM-CSF + IL-4 alone and those cultured in medium supplemented with Flt3L (Fig. 2). These observations were similar for cells from patients with SIL and healthy donors.

We also compared the phenotype of DC generated with and without Flt3L by FACS analysis. DC could be distinguished from contaminating lymphocytes by their size and granularity. As shown in Fig. 3A, gated cells containing DC presented significantly increased forward-scatter and side-scatter values as compared with lymphocytes. Therefore, we used these parameters to gate the DC. The gated cell population was similar for cultures unsupplemented or supplemented with Flt3L. Between $20 \%$ and $75 \%$ of the cells cultured without Flt3L were in this gate compared to $30 \%-80 \%$ for cells generated with Flt3L. Thus, the DC differentiation pathway (with and without Flt3L) was associated with the same changes in size and granularity, leading to cells that were considerably larger and more dense than granulocytes and monocytes. Figure 3B demonstrates that the cells generated with or without Flt3L display the typical surface phenotype of dendritic cells [32]: (1) expression of the Langerhans/dendritic cell molecule CD1a, (2) co-expression of CD4, and (3) absence of the macrophage and T cell markers CD14 and CD3. However, small numbers of $\mathrm{CD}^{+}$and $\mathrm{CD} 20^{+}$(not shown) cells were detected by FACS analysis in the gated cell population and were probably related to the formation of cell "rosettes" between DC and either T cells or B cells. Other typical features included (4) increased expression of class II MHC (HLA-DR) molecules, (5) high-level expression of the adhesion molecules ICAM-1 (CD54) and CD40, and (6) expression of the co-stimulatory molecules B7.1 (CD80) and B7.2 (CD86). No differences were observed in the level of expression of all these markers in cultures with and without Flt3L. Patients with SIL did not differ significantly from control individuals.

Effects of Flt3L on the yield of DC in patients with cervical SIL and healthy donors

The effect of Flt3L on $\mathrm{CD}_{1}{ }^{+}$cell generation was examined using peripheral blood from 15 patients with HPV-associated SIL and 6 healthy donors. At day 7, cells cultured in GM-CSF + IL-4, with or without Flt3L, were counted and the number of $\mathrm{CD} 1 \mathrm{a}^{+}$cells was determined by FACS analysis. Addition of Flt3L to the culture medium did not result in a significant increase in the total number of cells either in patients with SIL or in healthy donors (data not shown). In contrast, the addition of Flt3L induced an important and significant expansion of $\mathrm{CD}^{+}{ }^{+}$cells either in patients with SIL $(P<0.0001)$ or in control individuals $(P=0.0312)$. The results are expressed, in Fig. 4, as the percentage increase in $\mathrm{CD}^{+}{ }^{+}$cells, compared with cells cultured in normal medium (GM-CSF + IL-4 alone), for each PBMC donor.

Interestingly, the proportion of DC obtained in cultures without Flt3L from patients with SIL was the same as that from control individuals. When Flt3L was added, this proportion increased, but to the same extent in both patients and healthy individuals (data not shown).

The effect of Flt $3 \mathrm{~L}$ on the yield of $\mathrm{CD} \mathrm{a}^{+}$cells varied among donors. The individual increments observed with Flt $3 \mathrm{~L}$ varied between $18 \%$ and $53 \%$ with a mean in- 
Fig. 2A, B Morphology of DC cultured in medium containing GM-CSF and IL-4 and supplemented with Flt3L (A) or unsupplemented (B). The cytospins were colored with May-Grumwald-Giemsa stain. Cells display a dendritic morphology with delicate membrane projections
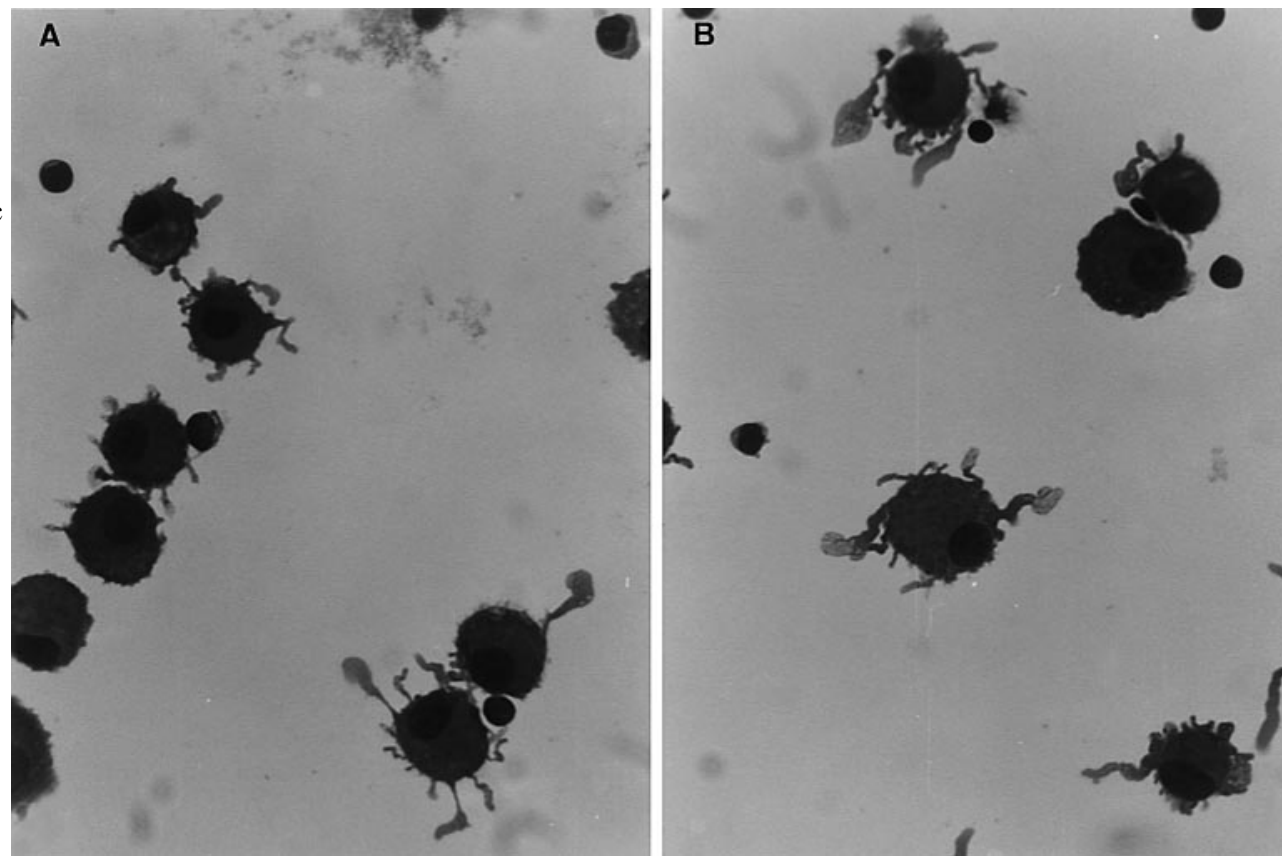

crease of $26 \%$ for the patients and $34 \%$ for the healthy donors. This difference was not significant.

When Flt3L was added to the culture, $(1.14 \pm 0.26) \times 10^{6}(n=7) \mathrm{CD}^{2} \mathrm{a}^{+}$cells were obtained after 7 days from blood samples having a volume as low as $10 \mathrm{ml}$. Similar results were obtained for both patients and healthy individuals.

Functionality of DC generated with and without Flt3L. Allostimulatory capacity

Cell populations from cultures with and without Flt3L for one healthy donor and two patients with SIL were compared for their capacity to provide accessory signals for an efficient proliferation of responder cells in an allogeneic test.

As shown in Fig. 5, the capacity to produce a potent mixed lymphocyte reaction was retained even at stimulator:responder ratios as low as 1000:100 000, which is consistent with a DC-mediated T cell response [47]. DC generated from precursors in the peripheral blood of patients and DC obtained from healthy donors did not differ significantly in their ability to stimulate an allogeneic response.

The stimulatory capacity of the cell population generated with GM-CSF + IL-4 + Flt3L was generally higher than that of the population induced with GMCSF + IL-4. These results support the idea that there was a higher proportion of stimulatory cells (i.e. DC cells) in the populations generated with Flt3L.

PBMC from the same donors were used as controls and were much less effective in all assays. Independently of the cytokines used to generate DC, mixed lymphocyte reactivity correlated with the percentage of $\mathrm{CD}^{+} \mathrm{a}^{+} /$
CD14- cells present among stimulating cells (data not shown).

\section{Discussion}

This study was designed to assess the optimal modalities for the large-scale procurement of functional DC starting from a relative small quantity $(10 \mathrm{ml})$ of peripheral blood from patients with preneoplastic lesions of the uterine cervix (SIL) and to determine whether the generation of DC differs between healthy women and patients with SIL, since tumor-derived factors have been shown to affect the ability of precursors to differentiate into DC [12]. Moreover, previous studies have reported a depletion and qualitative alterations of Langerhans cells in SIL compared to a normal squamous mucosa during the HPV-associated cervical carcinogenesis [1, 45]. This finding might be due to an altered generation of DC or to a lack of maturation/migration of DC in relation to a decreased production of chemotactic factors by epithelial cells in the presence of HPV [14]. Because of the central role of DC in the generation of an effective cellular immune response, a defect in these cells might make the development of a specific CTL response almost impossible in neoplastic cervical epithelium infected with HPV. These observations highlight the need for methods generating a large-scale production of DC in vitro for a better understanding of their role in HPV-associated (pre)neoplastic lesions. The development of methods generating a large number of functionally active DC was prompted by studies suggesting that administration of tumor-antigen-pulsed DC to cancer patients might help to counteract disturbance of immune functions [15]. In the field of HPV-associated pathology, some experiments have shown that a protective and therapeutic 

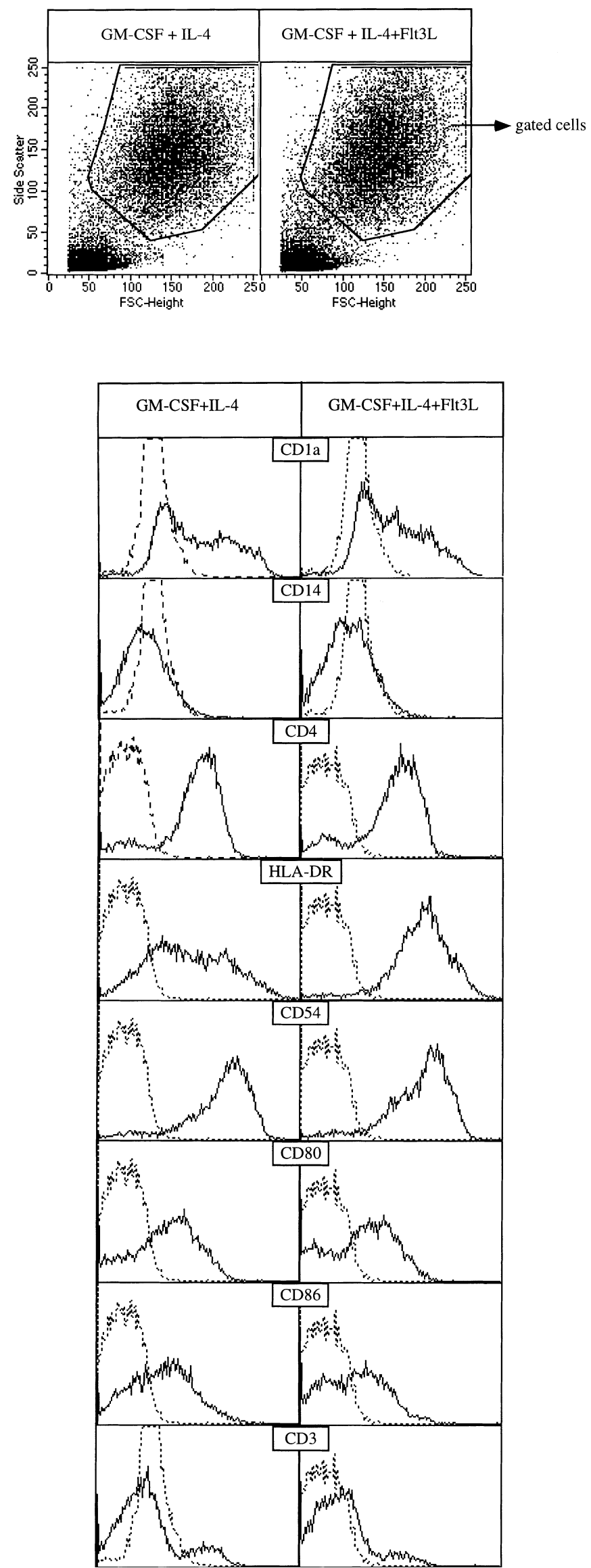

Fig. 3A, B Cell-surface membrane phenotype of DC generated on day 7 with and without Flt3L as detected by dual-color direct immunofluorescence and flow cytometry. A DC can be distinguished in the two culture conditions by their high forward- and side-scatter properties. B DC display the typical phenotype of dendritic cells in the two culture conditions. Patterns of isotypematched control antibodies are included in each histogram (dotted lines). Fluorescence intensity ( $x$ axis) is plotted against the number of events ( $y$ axis). Each result is representative of seven experiments

antitumor immunity may be generated against HPVtransformed cells in animals by using vaccination protocols with viral-peptide-pulsed autologous DC [26, 52]. In humans, this approach was shown to be effective for inducing peptide-specific CTL that recognise processed E6 and E7 peptides in vitro [9]. An efficient expansion of autologous DC might therefore be clinically useful. Several investigators have shown that DC may be generated in liquid suspension cultures from blood monocytic precursors by using a combination of GM-CSF and IL-4 [17, 35, 37]. However, this technique is limited by the low frequency of monocytic precursors. The hematopoietic activity of some stimulatory factors such as Flt3L [11, 23, 24] might help to improve the production of DC from PBMC. Currently, hematopoietic growth factors have been tested for their effect on bone marrow progenitor cells $[25,41,43]$ and not on monocytic precursors. By using a combination of IL-4 $(100 \mathrm{U} / \mathrm{ml})$, GM-CSF $(800 \mathrm{U} / \mathrm{ml})$ and Flt3L $(40 \mathrm{ng} / \mathrm{ml})$, we were able to produce, after 7 days of culture, between $1.14 \times 10^{6}$ and $1.4 \times 10^{6} \mathrm{CD} \mathrm{a}^{+}$cells from the adherent fraction of $10 \times 10^{6}$ PBMC (present in $8-10 \mathrm{ml}$ peripheral blood of healthy individuals and patients with cervical SIL). The generation of DC from monocytic precursors was maximal in the presence of $100 \mathrm{U} / \mathrm{ml} \mathrm{IL}$ 4. Previous studies used higher concentrations of IL-4 (500-1000 U/ml IL-4) and no Flt3L [33, 37, 39] and reported a yield of DC $\left(3 \times 10^{6} \mathrm{CD}^{+} \mathrm{a}^{+}\right.$cells for $40 \mathrm{ml}$

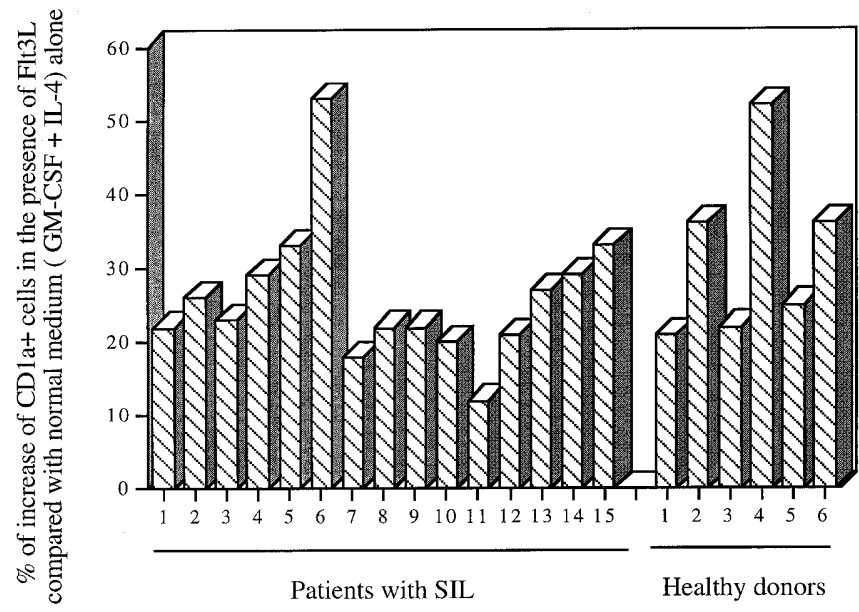

Fig. 4 Individual percentage $\mathrm{CDla}^{+}$cell increases in the presence of Flt3L $(40 \mathrm{ng} / \mathrm{ml})$ compared with number of $\mathrm{CDla}^{+}$cells generated in medium with GM-CSF + IL-4 alone. Results are shown for patients with SIL and healthy donors 
blood) that is lower than that obtained in this study. We found that higher IL-4 concentrations than $100 \mathrm{U} / \mathrm{ml}$ were associated with a decrease in the number of total mononuclear cells and consequently in the number of $\mathrm{CDla}^{+}$cells. Moreover, low concentrations of IL-4 are closer to the equilibrium constant of that cytokine in vivo (50-200 U/ml). These low concentrations of IL-4 also induce not only a differentiation of monocytes to DC but $36 \%$ of these DC show the presence of intracytoplasmic granules that are reminiscent of Langerhans cell Birbeck granules (Dr. Grassi, personal communication). Therefore, the use of $100 \mathrm{U} / \mathrm{ml} \mathrm{IL}-4$ may generate cells morphologically closer to Langerhans cells, the density of which has been shown to be low in HPV-transformed (pre)neoplastic cervical epithelium. The combination of Flt3L + GM-CSF + IL-4 was associated with a mean increase of $26 \%$ in DC production, compared with a culture without Flt3L. The precise mechanism of action by which Flt3L, in association with GM-CSF and IL-4, stimulates the production of DC remains unclear and requires further studies. One possibility is that Flt3L acts on $\mathrm{CD}_{3} 4^{+}$cells present in the adherent fraction of PBMC. Indeed, recent studies indicate that Flt3 receptor is expressed on purified CD34 ${ }^{+}$cells [44] and absent on CD34- cells [11]. Moreover, a variable number of $\mathrm{CD}^{+} 4^{+}$cells in each donor might explain the variable increase in CD1a ${ }^{+}$cells with Flt3L. However, it is very difficult to determine whether the percentage of CD34 ${ }^{+}$ cells in the starting population accounts for the interdonor variation because the frequency of these progenitors is too low to be detected with accuracy by FACS analysis. Another possibility is that Flt3L synergizes with GM-CSF to stimulate the proliferation and differentiation of monocytic cells [42]. Since the combination GM-CSF + IL-4 acts on the monocytic precursor population to induce DC differentiation [37], Flt3L might increase the yield of DC by stimulating the proliferation of monocytes and so boosting the level of precursor cells $\left(\mathrm{CD} 14^{+}\right)$.
We did not detect any significant difference in the phenotypical profile of DC generated with or without Flt3L. The generated cells were positive for the classical DC markers (CD1a, CD4, class II MHC, CD80, CD86, CD54, CD40). These molecules were highly expressed without major changes in antigen density. Further functional analysis revealed that the ability to stimulate allogeneic responder cells (PBMC) was retained in GMCSF + IL-4 + Flt3L cultures. We also compared the phenotype and the functionality of DC generated from the peripheral blood of healthy donors and from patients with SIL. There was no significant difference in the phenotype and functional activity of DC between control individuals and patients with SIL. The increased DC yield induced by Flt3L was also observed in both populations. The systemic alterations of the immune system observed in patients with SIL [18] do not seem, therefore, to influence the presence of DC precursors in the blood, and the decrease of Langerhans cells observed in SIL is probably related to local mechanisms (such as lack of maturation in situ or lack of chemotactic factors produced by HPV-infected keratinocytes) rather than a systemic mechanism affecting DC precursors.

In summary, we have described a simple method allowing the generation of a large number of functional DC from a relatively small amount of blood in both healthy donors and patients with SIL. The results of this study suggest that Flt3L is a promising growth factor for the in vitro generation of large number of DC, which might help to improve our understanding of the cervical carcinogenesis and be used in clinical immunotherapeutic anti cancer protocols.

Acknowledgements This work was supported by the Centre de Recherche Interuniversitaire en Vaccinologie with a grant from the Walloon Region and SmithKline Beecham Biologicals, the Fund for Medical Scientific Research the Oeuvre Belgc du Cancer and the Centre Anti-Cancereux près l'Université de Liège. Dr. P. Delvenne is a research associate of the Belgian National Fund for Scientific Research. We thank Dr. M. Lambot for interesting discussions and
Fig. 5 Comparison of the stimulatory capacity of cells obtained with GM-CSF + IL-4 (hatched bars), GM$\mathrm{CSF}+\mathrm{IL}-4+$ Flt3L (dotted bars) and PBMC (solid bars) for one healthy donor and two patients with SIL. Flt3L does not alter the ability to stimulate a potent mixed lymphocyte reaction. $\left[{ }^{3} \mathrm{H}\right]$ Thymidine uptake is expressed as counts per minute. Results represent the mean$\mathrm{s} \pm \mathrm{SE}$ of triplicate samples

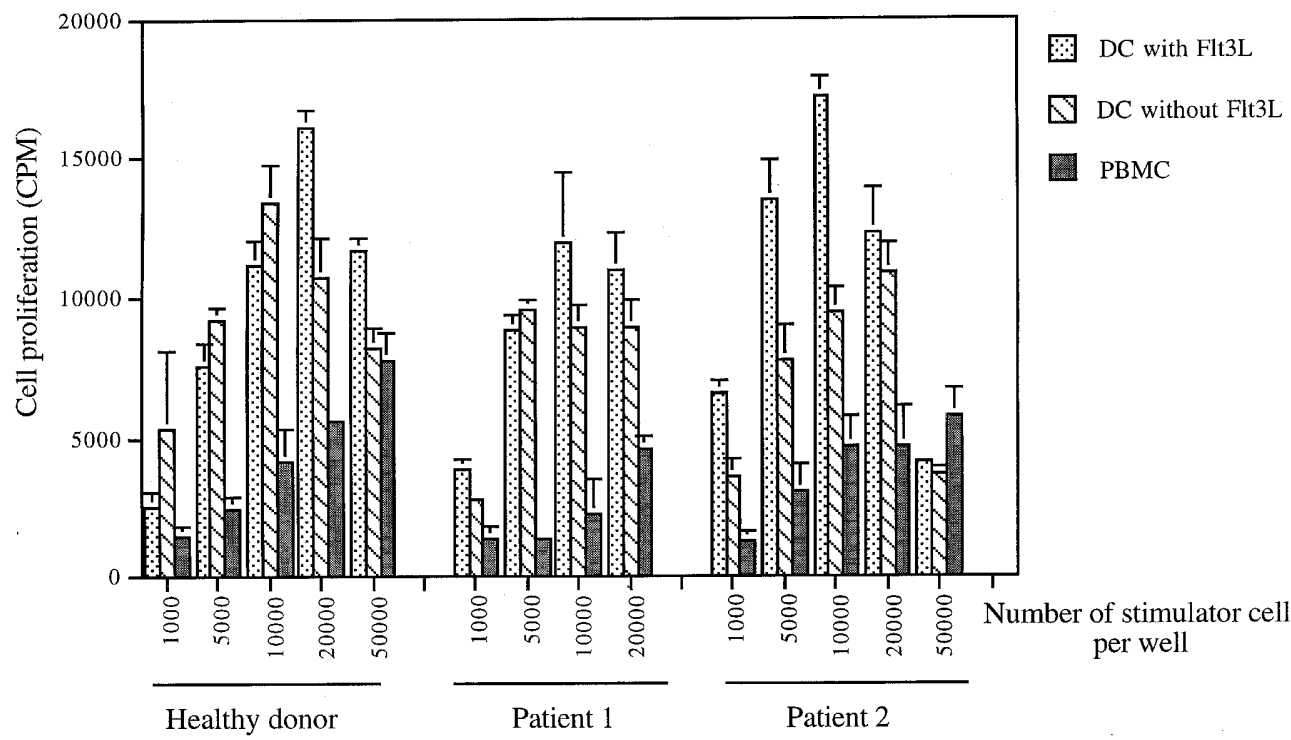


helpful suggestions, Dr. S.L. Giannini for critical review of this manuscript, Dr. N. Jacobs for help in FACS analysis and Dr. A. Gossens (Schering-Plough, Brussels) for kindly providing recombinant human GM-CSF.

\section{References}

1. Al-Saleh W, Delvenne P, Arrese Estrada J, Nikkels AF, Pierard JE, Boniver J (1995) Inverse modulation of intraepithelial Langerhans' cell and stromal macrophage/dendrocyte populations in human papillomavirus-associated squamous intraepithelial lesions of the cervix. Virchows Arch 427:41

2. Al-Saleh W, Giannini S, Jacobs N, Moutschen M, Doyen J, Boniver J, Delvenne P (1998) Correlation of T helper secretory differentiation and types of antigen-presenting cells in squamous intraepithelial lesions of the uterine cervix. J Pathol $184: 283$

3. Bernhard H, Disis ML, Heimfeld S, Hand S, Gralow JR, Cheever MA (1995) Generation of immunostimulatory dendritic cells from human CD $34^{+}$hematopoietic progenitor cells of the bone marrow and peripheral blood. Cancer Res 55:1099

4. Bhardwaj N, Young JW, Nisanian AJ, Baggers J, Steinman RM (1993) Small amounts of superantigen, when presented on dendritic cells, are sufficient to initiate T cell responses. J Exp Med 178:633

5. Castello G, Esposito G, Giovanni S, Mora LD, Abate G, Germano A (1986) Immunological abnormalities in patients with cervical carcinoma. Gynecol Oncol 25:61

6. Caux C, Vanbervliet B, Massacrier C, Azuma M, Okumura K, Lanier L, Banchereau J (1994) B70/B7-2 is identical to CD86 and is the major functional ligand for CD28 expressed on human dendritic cells. J Exp Med 180:1841

7. Caux C, Liu YJ, Banchereau J (1995) Recent advances in the study of dendritic cells and follicular dendritic cells. Immunol Today $16: 2$

8. Di Girolama W, Goni J, Laguens RP (1985) Langerhans' cells in squamous metaplasia of the human uterine cervix. Gynecol Obstet Invest 19:38

9. Evans EM, Man S, Evans AS, Borysiewicz LK (1997) Infiltration of cervical cancer tissue with human papillomavirusspecific cytotoxic T-lymphocytes. Cancer Res 57:2943

10. Freudenthal PS, Steinman RM (1990) The distinct surface of human blood dendritic cells, as observed after an improved isolation method. Proc Natl Acad Sci USA 87:7698

11. Gabbianelli M, Pelosi E, Montesoro E, Valtieri M, Luchetti L, Samoggia P, Vitelli L, Barberi T, Testa U, Lyman S, Peschle C (1995) Multi-level of flt3 ligand on human hematopoiesis: expansion of putative stem cells and proliferation of granulomonocytic progenitors/monocytic precursors. Blood 86: 1661

12. Gabrilovich D, Corak J, Ciernik IF, Kavanaugh D, Carbone DP (1997) Decreased antigen presentation by dendritic cells in patients with breast cancer. Clin Cancer Res 3:483

13. Giannini SL, Al-Saleh W, Piron H, Jacobs N, Doyen J, Boniver $J$, Delvenne $P$ (in press) Cytokine expression in squamous intraepithelial lesions of the uterine cervix: implications for the generation of local immunosuppression. Clin Exp Immunol

14. Heufler C, Koch F, Schuler G (1988) Granulocyte/macrophage colony-stimulating factor and interleukin 1 mediate the maturation of murine epidermal Langerhans cells into potent immuno-stimulatory dendritic cells. J Exp Med 167:700

15. Hsu FJ, Benike C, Fagnoni F, Liles TM, Czerwinski D, Taidi B, Engelman EG, Levy R (1996) Vaccination of patients with B-cell lymphoma using autologous antigen-pulsed dendritic cells. Nature Med 2:52

16. Hughes RG, Norval M, Howie SEM (1988) Expression of major histocompatibility class II antigens by Langerhan's cells in cervical intraepithelial neoplasia. J Clin Pathol 41:253

17. Inaba K, Inaba M, Romani N, Aya H, Deguchi M, Ikehara S, Meramatsu S, Steinamn RM (1992) Generation of large numbers of dendritic cells from mouse bone marrow cultures supplemented with granulocyte/macrophage colony-stimulating factor. J Exp Med 176:1693

18. Jacobs N, Giannini SL, Doyen J, Baptista A, Moutschen M, Boniver J, Delvenne P (1998) Inverse modulation of IL-10 and IL-12 in the blood of women with preneoplastic lesions of the uterine cervix. Clin Exp Immunol 111:219

19. Jansen JH, Wientjens G-JHM, Fibbe WE, Willemze R, KluinNelemans HC (1989) Inhibition of human macrophage colony formation by interleukin 4. J Exp Med 170:577

20. Knight SC, Stagg AJ (1993) Antigen-presenting cell types. Curr Opin Immunol 5:374

21. Lehtinen M, Rantala I, Toivonen A, Luoto H, Aine R, Lauslahti K, Ylä-Outinen A, Romppanen U, Paavonen J (1993) Depletion of Langerhans cells in cervical HPV infection is associated with replication of the virus. APMIS 101:833

22. Lorincz AT, Temple GF, Kurman RJ, Jenson AB, Lancaster WD (1987) Oncogenic association of specific human papillomavirus types with cervical neoplasia. J Natl Cancer Inst 79:671

23. Lyman SD (1966) Biology of Flt3 ligand and receptor. Int J Hematol 62:63

24. Lyman SD, James L, VandenBos T, de Vries P, Brasel K, Gliniak B, Hollingsworth LT, Picha KS, McKenna HJ, Splett RR, Fletcher FF, Maraskovsky E, Farrah T, Foxworthe D, Williams DE, Beckmann MP (1933) Molecular cloning of a ligand for the flt $3 / \mathrm{flk}-2$ tyronise kinase receptor:a proliferative factor for primitive hematopoietic cells. Cell 75:1157

25. Maraskovsky E, Brasel K, Teepe M, Roux ER, Lyman SD, Shortman K, McKenna HJ (1996) Dramatic increase in the numbers of functionally mature dendritic cells in Flt3 ligandtreated mice:multiple dendritic cells subpopulations identified. J Exp Med 184:1953

26. Mayordomo JI, Zorina T, Storkus WJ, Zitvogel L, Celluzzi C, Falo LD, Melief CJ, Ildstad ST, Kast WM, Deleo AB, Lotze MT (1995) Bone marrow-derived dendritic cells pulsed with synthetic tumour peptides elicit protective and therapeutic antitumour immunity. Nat Med 1:1297

27. McArdle JP, Muller HK (1986) Quantitative assessement of Langerhans' cells in human cervical intraepithelial neoplasia and wart virus infection. Am J Obstet Gynecol 154:509

28. Moore TA, Zlotnik A (1997) Differential effects of Flk-2/Flt-3 ligand and stem cell factor on murine thymic progenitor cells. J Immunol 158:4187

29. Morelli A, Larregina A, Dipaola G, Fainboim L (1991) Intraepithelial CD1 positive Langerhans cell precursor in transformation zone squamous metaplasia. Cervix 9:69

30. Morelli AE, Sananes C, Di Paola G, Paredes A, Fainboim L (1993) Relationship between types of human papillomavirus and Langerhans' cells in cervical condyloma and intraepithelial neoplasia. Am J Clin Pathol 99:200

31. Nuovo GJ, Friedman D (1990) In situ hybridization analysis of HPV DNA segregaton patterns in lesions of the female genital tract. Gynecol Oncol 36:256

32. Peters JH, Gieseler R, Thiele B, Steinbach F (1996) Dendritic cells:from ontogenetic orphans to myelomonocytic descendants. Immunol Today 17:273

33. Radmayr C, Böck G, Hobisch A, Klocker H, Bartsch G, Thurnher M (1995) Dendritic antigen-presenting cells from the peripheral blood of renal-cell-carcinoma patients. Int $\mathbf{J}$ Cancer 63:627

34. Reid CDL, Fryer PR, Clifford C, Kirk A, Tikerpae J, Knight SC (1990) Identification of hematopoietic progenitors of macrophages and dendritic Langerhans cells (DLCFU) in human bone marrow and peripheral blood. Blood 76:1139

35. Reid CDL, Stackpoole A, Meager A, Tikerpae J (1992) Interactions of tumor necrosis factor with granulocyte-macrophage colony-stimulating factor and other cytokines in the regulation of dendritic cell growth in vitro from early bipotent $\mathrm{CD} 34^{+}$progenitors in human bone marrow. J Immunol 149:2681 
36. Romani N, Schuler G (1992) The immunologic properties of epidermal Langerhans cells as a part of the dendritic cell system. Springer Semin Immunopathol 13:265

37. Romani N, Gruner S, Brang D, Kämpgen E, Lenz A, Trockenbacher B, Konwalinka G, Fritsh PO, Steinman RM, Schuler G (1994) Proliferating dendritic-cell progenitors in human blood. J Exp Med 180:83

38. Rosini S, Caltagirone S, Tallini G, Lattanzio G, Demopoulos R, Piantelli M, Musiani P (1996) Depletion of stromal and intraepithelial antigen-presenting cells in cervical neoplasi in human immunodeficiency virus infection. Hum Pathol 27:834

39. Sallusto F, Lanzavecchia A (1994) Efficient presentation of soluble antigen by cultured human dendritic cells is maintained by granulocyte/macrophage colony-stimulating factor plus interleukin 4 and downregulated by tumor necrosis factor alpha. J Exp Med 179:1109

40. Santiago-Schwarz F, Belilos E, Diamond B, Carsons SE (1992) TNF in combination with GM-CSF enhances the differentiation of neonatal cord blood stem cells into dendritic cells and macrophages. J Leukoc Biol 52:274

41. Santiago-Schwarz F, Rappa Da, Laky K, Carsons SE (1995) Stem cell factor augments tumor necrosis factor-granulocytemacrophage colony-stimulating factor-mediated dendritic cell hematopoiesis, Stem Cells 13:186

42. Shurin MR, Pandharipande PP, Zorina TD, Haluszczak C, Subbotin VM, Hunter O, Brumfield A, Storkus WJ, Maraskovsky E, Lotze MT (1997) FLT3 ligand induces the generation of functionally active dendritic cells in mice. Cell Immunol 179:174

43. Siena S, Di Nicola M, Bregni M, Mortarini R, Anichini A, Lombardi L, Ravagnani F, Parmiani G, Gianni AM (1995) Massive ex vivo generation of functional dendritic cells from mobilized $\mathrm{CD} 34^{+}$blood progenitors for anticancer therapy. Exp Hematol 23:1463
44. Small D, Levenstein M, Kim E, Carow C, Amin S, Rockwell P, Witte L, Burrow C, Ratajczak MZ, Gewirtz AM, Civin CI (1994) STK-I, the human homolog of flk $2 / \mathrm{flt} 3$, is selectively expressed in CD $34^{+}$human bone marrow cells and is involved in the proliferation of early progenitor/stem cells. Proc Natl Acad Sci USA 91:459

45. Smolle J, Soyer HP, Ehall R, Bartenstein S, Kerl H (1986) Langerhans cell density in epithelial differentiation but not with the peritumoral infiltrate. J Invest Dermatol 87:477

46. Sornasse T, Flamand V, Becker GD, Bazin H, Tielemans F, Thielemans K, Urbain J, Leo O, Moser M (1992) Antigenpulsed dendritic cells can efficiently induce an antibody response in vivo. J Exp Med 175:15

47. Steinman RM, Witmer MC (1978) Lymphoid dendritic cells are potent stimulators of the primary mixed leukocyte reaction in mice. Proc Natl Acad Sci USA 75:5132

48. Tang A, Amagai M, Granger LG, Stanley JR, Udey MC (1993) Adhesion of epidermal Langerhans cells to keratinocytes mediated by E-cadherin. Nature 361:82

49. Tay SK, Jenkins D, Maddox P, Campion M, Singer A (1987) Lymphocyte phenotypes in cervical intraepithelial neoplasia and human papillomavirus infection. Br J Obstet Gynaecol 94:16

50. Thivolet J, Viac J, Staquet MG (1982) Cell mediated immunity in wart virus infection. Int J Dermatol 21:94

51. Young JW, Inaba K (1996) Dendritic cells as adjuvants for class I major histocompatibility complex-restricted antitumour immunity. J Exp Med 183:7

52. Zitvogel L, Mayordomo JI, Tjandrawan T, Deleo AB, Clarke MR, Lotze MT, Storkus WJ (1996) Therapy of murine tumors with tumor peptide-pulsed dendritic cells:dependence on $\mathrm{T}$ cells, B7 costimulation, and T helper cell 1 associated cytokines. J Exp Med 183:87 